
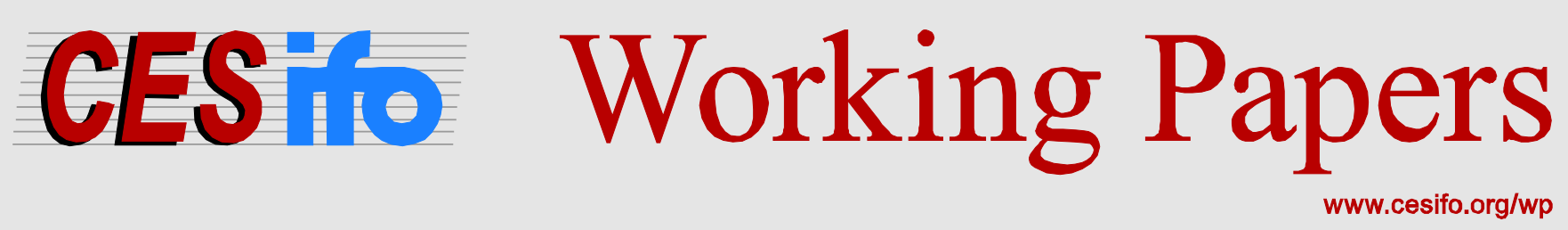

\title{
The Effects of School Integration: Evidence from a Randomized Desegregation Program
}

\author{
Peter Bergman
}

CESIFO WORKING PAPER NO. 6119

CATEGORY 5: ECONOMICS OF EDUCATION

OCTOBER 2016

An electronic version of the paper may be downloaded

- from the SSRN website:

- from the RePEc website:

- from the CESifo website:

wWw.SSRN.com

Www.RePEc.org

www.CESifo-group.org/wp 


\title{
The Effects of School Integration: Evidence from a Randomized Desegregation Program
}

\begin{abstract}
This paper studies the impact of a desegregation ruling on several medium-run outcomes. This ruling mandates that seven school districts, which serve higher-income, predominantly-white families, accept a group of minority elementary school students who apply to transfer from a nearby, predominantly-minority school district. Slots are allocated via lottery. The offer to transfer raises college enrollment by 10 percentage points. This is due to greater attendance at two-year colleges and particularly for male students. There is evidence male students are also more likely to vote. In contrast, transferring increases the likelihood of arrest. This is driven by increases in non-violent offenses.
\end{abstract}

JEL-Codes: I200, I210, I240, I280.

\author{
Peter Bergman \\ Teachers College \\ Columbia University \\ 525 W. $120^{\text {th }}$ Street \\ USA - New York, New York 10027 \\ bergman@tc.columbia.edu
}

I thank Dionissi Aliprantis, Clive Belfield, Sandy Black, Sue Dynarski, Matt Hill, Peter Hinrichs, Max Kasy, Hank Levin, Leigh Linden, Krzysztof Karbownik, Day Manoli, Paco Martorell, Parag Pathak, Todd Rogers, Heather Schwartz, Marty West and seminar participants at AEFP, the Cleveland Federal Reserve, Hebrew University, the Institute for Research on Poverty, IZA/SOLE Conference, NBER Education Program Meeting, New York Federal Reserve, Stanford University and UT Austin for their suggestions. I also thank Josefa Aguirre and Kenneth Lim for excellent research assistance. I am grateful to the WT Grant Foundation and Teachers College, Columbia University for funding to support this research. All errors are my own. Website: www.columbia.edu/ psb2101 


\section{Introduction}

More than 50 years after the Supreme Court ruled that school integration must proceed with "all deliberate speed," segregation across neighborhoods persists (Reardon and Owens, Forthcoming). This fact is unsettling because segregation is correlated with a number of adverse outcomes, such as higher rates of poverty and crime (Ludwig et al., 2012). Across schools, segregation is associated with fewer resources, lower peer quality and poor performance (Card and Rothstein, 2007; Reber, 2010; ?; Vigdor and Ludwig, 2007). Yet it is unclear to what degree neighborhood and school segregation contributes to these poor education outcomes. The Moving to Opportunity (MTO) housing-mobility experiment generated large reductions in neighborhood poverty rates and modest reductions in share minority for the experimental group, but had small impacts on school environment and short-run academic outcomes overall (Sanbonmatsu et al., 2006). Other analyses on the impact of neighborhoods on children's outcomes find heterogeneous effects (Rosenbaum, 1991; Gould et al., 2011) and beneficial effects for children whose families moved when they were young (Schwartz, 2010; Chetty et al., 2016). A complementary experiment would help answer an important question for child development: Holding neighborhood characteristics constant, does access to low-minority share, higher-income school districts improve child outcomes?

This question is difficult to answer because most school-choice and school-integration plans shift students between schools within a district, but the largest determinant of segregation is across school districts (Fiel, 2013). Moreover, it is difficult to find exogenous variation in access to low-minority-share schools for minority students. This paper addresses these difficulties by studying an on-going, court-settled desegregation program. In contrast to the typical integration plan, the program studied here offers to transfer a small population of minority students from a low-income, predominantly Black and Hispanic-attended school district to school districts that serve a higher income, predominantly-white demographic. Each year, families with minority children about to enter kindergarten, first or second grade 
are eligible for a transfer to one of seven receiving districts. Students in other grades are ineligible. Importantly, the program is oversubscribed so a fixed number of applicants are selected at random and assigned to a receiving district. In the years studied here, no more than 200 students are assigned across the seven districts each year. Once assigned, students can remain in the district as long as they do not move from the sending district boundaries. Thus students who win the lottery gain access to higher-resource, majority-white schools at an early age, but cannot change neighborhoods without being removed from the program.

I link application data to several medium-run outcomes for participants including college enrollment, public arrest records, and voter records. I find that access to low-minority share, higher-income districts has a large impact on college enrollment. Overall, the offer to transfer school districts increases the likelihood of attending college by 10 percentage points. The effects are concentrated in attendance to public, two-year colleges. There is no overall effect on the likelihood of attending private colleges.

These impacts are heterogeneous. Male students become more likely to attend two year, four year, public or private colleges, while enrollment impacts are significantly smaller for female students. In line with the larger impacts on college enrollment, there is some evidence male students are also more likely to vote as well. There is no effect on the likelihood of voting overall however.

In striking contrast, there is a significant overall increase in the likelihood of arrest. Again, this is particularly true for male students, with no effects on female students. This increase in arrests is primarily driven by offenses that are non-violent, such as driving with a suspended license followed by drug and property-related offenses. A significant share of arrests occur outside the sending district. I present evidence that the integration program causes students to traverse areas farther from home, which could expose them to greater risk of arrest for non-violent or driving-related offenses.

A number of papers have studied the effects of district-wide, court-ordered desegregation, primarily implemented during the 1960s and 1970s, and found evidence of increased attain- 
ment for Black students (Guryan, 2004; Reber, 2010; Johnson, 2015). More recently, Lutz (2011) and Billings et al. (2013) study the end of court-ordered desegregation. Billings et al. (2013) examine Charlotte-Mecklenburg schools and find increases in segregation and disparities between minorities and whites. Terminating school integration modestly decreased test scores, increased crime among minority males and lowered attainment. Interestingly, older random-assignment studies of desegregation show no effect on short-run academic achievement (Cook, 1984; Rivkin and Welch, 2006).

This paper also relates to research by Angrist and Lang (2004), who studied peer effects of the Metco program, which is a similar, though not lottery-based, transfer program across districts. The authors focus on the impact of transfer students on receiving students and find little impact, but there are small negative effects on certain minority receiving students. Thus a key distinction between this paper and the research by Angrist and Lang (2004) is that they study the effects on receiving students while this paper studies the effects on the transferring students.

In addition to studying the long-run impacts of a desegregation program, this paper also contributes to research on how schools impact longer-run outcomes for students. Several papers examine the effects of high-performing charter schools on college attendance and nonacademic outcomes. Angrist et al. (2013) use admission lotteries to show significant, causal effects of a group of Boston-area charter schools attendance on college attendance, which shift students from attending two-year colleges to four-year colleges. Likewise, Dobbie and Fryer (2013) gathered admission lottery and survey data to study a range of students' medium-run outcomes, including college enrollment and risky behaviors. They find a similar effect on college attendance and also a reduction in teen pregnancy for students who attend schools in the Harlem Children's Zone. Booker et al. (2014) use non-experimental estimates that suggest charter schools impact post-secondary attainment and earnings. Deming et al. (2014) show that in Charlotte-Mecklenburg Schools, which offers school choice, the opportunity to attend a first-choice high school improves post-secondary outcomes. 
In general, these studies measure the impact of high-quality middle and high schools. This paper complements the research above by studying the effect of lottery-based access to schools at much earlier ages, when children begin elementary school, which is potentially a critical period of human capital investment (Cunha and Heckman, 2007; Heckman and Carneiro, 2003).

More broadly, researchers have examined neighborhood effects on a number of longer-run outcomes of children. Revisiting the Moving to Opportunity housing mobility experiment, Chetty et al. (2016) find substantial increases in college enrollment and earnings for families with young children who moved to low-poverty neighborhoods. However Gennetian et al. (2012) show evidence of an increase in the likelihood of arrest for property-related crimes, and Kling et al. (2005) find increases in property-related arrests for males. Lastly, Magre et al. (2014) looks at how MTO impacted voting behavior and finds evidence that MTO results in lower voter participation rates.

There has been less evidence using experimental variation in schooling to study voting behaviors. Milligan et al. (2004) and Dee (2004) use instrumental variables to identify causal effects of schooling on voting behaviors, and they find positive impacts. Sondheimer and Green (2010) analyze several education-related interventions on voting behaviors, including the "I Have a Dream" promise scholarship program, the Perry Preschool experiment and the Tennessee STAR class-size reduction experiment. The authors also find a positive impact on voter participation.

The rest of this paper is organized as follows. Section II provides background information on the transfer program and participating school districts. Section III describes the data and empirical strategy. Section IV presents the results, Section V provides discussion, and Section VI concludes. 


\section{Background}

While the 1954 Brown v. Board of Education decision mandated the end of racial segregation in schools, Milliken $v$. Bradley (1974) impeded the ability of policymakers to integrate schools across district boundaries (Fiel, 2013). Under this restriction, large-scale busing programs often shifted students across schools within districts. However, factors such as suburban migration and "white flight" (Welch and Light, 1987; Reber, 2005) led to changing white enrollment shares within districts that limited the scope for school integration based on within-district policies. Coleman et al. (1975) find that while within-district segregation decreased during this time period, it was partly offset by increases in interdistrict segregation (Reber, 2005). The sorting of families across neighborhoods, and in turn district boundaries, became central to interracial contact in schools (Rivkin and Welch, 2006).

In contrast to more common intradistrict-desegregation programs, the desegregation program studied in this paper is an interdistrict, voluntary-transfer program. This program is borne out of a court ruling in 1976. Following racially motivated fights in local high schools and the contentious drawing of district boundaries, parents filed a class-action lawsuit against a group of school districts and two counties in Northern California (Jones, 2006). The plaintiffs argued that the racial segregation in eight school districts across the two counties was unconstitutional. Ten years later, a court settlement mandated district participation in a transfer program if less than $60 \%$ of that district is composed of minority students.

This program offers minority students from a predominantly minority school district the opportunity to transfer to districts that are majority white, and vise versa. ${ }^{1}$ Minority students originating from the Ravenswood City School District may apply to transfer to one of seven school districts: Palo Alto Unified, Las Lomitas, Menlo Park, Portola Valley, BelmontRedwood Shores-Redwood Shores, Woodside and San Carlos. The program has the explicit goal of reducing "the racial isolation of students of color in the Palo Alto, Ravenswood,

\footnotetext{
${ }^{1}$ Over the entire history of the transfer program, only two students have transferred into the predominantly minority school district.
} 
and other San Mateo County School Districts." 2 The court ordered each district to receive a fixed number of students according to their student enrollment at the time of the settlement. Palo Alto receives the most students, 60, and Woodside receives five students, which is the fewest. ${ }^{3}$ Per-pupil funding for these students is divided between Ravenswood and the receiving districts, with $70 \%$ going to the receiving district. To put these numbers in perspective, the program offers 166 slots, primarily for entering kindergarten students, and the kindergarten class for Ravenswood was 580 students in 2000. ${ }^{4}$ Typical enrollment in the transfer program is roughly 150 students.

Applications are restricted to rising kindergarten, first and second-grade students. Students are assigned to districts via a lottery. Once accepted, districts have discretion over which particular school that child attends if more than one elementary school operates within that district. If a student is not accepted, the family may reapply the following year if they are still in an eligible grade. Once a student has transferred, the student may remain in the receiving school district throughout all of the grades the district offers so long as they reside within the Ravenswood City School District boundaries. If a student leaves the program after the second grade they are not permitted to return.

The application and assignment process proceeds as follows. ${ }^{5}$ Applications are available in English and Spanish, are made available online, and are distributed to schools and via mass mailing. Families fill out an application in which they write down their district preference rankings (1st choice through 7th choice), their child's grade, their child's race and whether another sibling is enrolled in the program. Importantly, families are only eligible to transfer to a district they list on their application. If, for example, a family only writes down two choices, they only have a chance for admission to those two districts. Families mail or hand deliver this application to the San Mateo County Office of Education.

\footnotetext{
${ }^{2}$ This statement is an excerpt from the Palo Alto School District website describing the program: http://pausd.org/parents/programs/VoluntaryTransfer/

${ }^{3}$ More slots may open if students who have transferred leave the program in later years.

${ }^{4}$ Enrollment information from Ed-Data.

${ }^{5}$ This description of the lottery process is based on documentation provided by San Mateo County and the consultant hired to code the lottery program.
} 
The county uses a mechanism known to the school assignment literature as "serial dictatorship" to assign students to district slots. Importantly, this assignment mechanism is strategy proof (Pathak, 2011). Strategy proof implies that it is suboptimal to "game" the system in that the optimal strategy for a parent to receive their preferred choice is to reveal their true preferences on the application form. Accordingly, the county sorts students by sibling priority group and grade and assigns a lottery number. Within a priority group, students assigned a low lottery number are likely to receive their first choice. If slots are all filled for a student's first choice, the process moves down to their second choice; if the slots for their second choice are filled as well, the process moves down to their subsequent choice (if listed), and so on. Then the process moves to the person with the lottery number one greater. Roughly $80 \%$ of students win an offer to transfer. As discussed below, this process has implications for the empirical strategy.

Figure 1 shows the geography the sending and receiving districts. Ravenswood City School District is predominantly located in East Palo Alto and adjacent to the San Francisco Bay. Menlo Park and Palo Alto share district boundaries with Ravenswood. Ravenswood serves grades K-8 and students' default high school for the sample in this study is located in Redwood City. All receiving districts offer grades K-8 with the exception of Palo Alto, which serves grades K-12. Redwood City, which also shares a boundary, has not participated in the program since 1994 because more than $60 \%$ of students are part of a minority-racial group, which is the bound for mandatory participation in the program.

Table 1 shows the distribution of families' district preferences and the minimum number of slots districts are mandated to make available to transfer students. Overwhelmingly families choose Palo Alto as their first-choice district, followed by Menlo Park. Interestingly, 56\% of families do not mark a third choice, which implies that if they do not receive an offer to transfer to either Menlo Park or Palo Alto, they will receive no offer to transfer to any other district. Nearly $90 \%$ of families do not mark a seventh choice. That Palo Alto is both the largest receiving district and the district most often ranked first is important for interpreting 
treatment effects. The impact of a transfer offer will largely identify the effect of receiving an offer to Palo Alto Unified School District.

There are several reasons families might rank Palo Alto and Menlo Park at the top of their preference list. First, these districts are nearest to Ravenswood, which may factor into family choices despite the fact that free transportation is provided. Proximity is a powerful determinant of choice; for instance, Hastings et al. (2005) find that an additional mile of driving distance reduces the odds of choosing a school by 30\%. Schools in Woodside and Portola Valley are 11 to 15 miles from Ravenswood - roughly a 30 minute drive away without traffic. Second, Palo Alto Unified School District has the benefit of offering enrollment through 12th grade. Students enrolled in other districts would revert back to the neighborhood school by default, which is in Redwood City. ${ }^{6}$

Table 2 provides summary statistics for each district using demographic and fifth grade test-score information from the California Department of Education, district finance information from the Common Core of Data, and census data, all from the year 2000, which is around when children in the sample entered school. Panel A shows district-level information for grade five and Panel B shows household-level information for families attending participating districts. Ravenswood has the second-highest student-teacher ratio, the lowest proportion of students classified as special education, the highest students classified as Limited-English Proficiency (LEP), the second-lowest per-pupil spending, and the lowest average proficiency level (Panel A). Ravenswood stands out particularly for LEP status: 65\% of students have Limited English Proficiency. The next closest district has $6 \%$ of students classified as LEP.

In terms of test scores, which average math and reading state-wide percentile ranks, the next-lowest performing district has a percentile rank more than twice as high as Ravenswood. Palo Alto ranks three times higher. Though not shown, these test-score disparities are similar between Palo Alto High School and the neighborhood high school for Ravenswood students:

\footnotetext{
${ }^{6}$ Recently, the school boundaries assigning the neighborhood high school have shifted for some students in the Ravenswood area, but this shift does not apply to the sample studied here.
} 
in the 9 th grade, average percentile rank in math and reading is 84 in the former and 40 in the latter.

Most districts far out spend Ravenswood as well. ${ }^{7}$ Menlo Park and Palo Alto, which receive the most students from Ravenswood, spend $62 \%$ more per pupil than Ravenswood City School District. ${ }^{8}$

Demographically, the differences between Ravenswood and other districts are stark. The former is predominantly Hispanic (64\%) and Black (24\%) with almost no white or Asian children. In contrast, Palo Alto children are $68 \%$ white, $19 \%$ Asian, 5\% Black and $7 \%$ Hispanic, which includes Ravenswood transfer students. The median income of Ravenswood residents is just over half of the median income for next poorest district $(\$ 45,573$ compared to $\$ 87,267)$. Overall, these numbers imply that students who win an offer to transfer may attend schools with significantly greater resources, wealthier surrounding families, and a student body that is largely white.

\section{Data and Empirical Strategy}

\section{A Data}

This study draws data from several sources. The first is program application data from 1998 until 2008. Records prior to 1998 are unavailable. These application data are recorded on spreadsheets and contain 2,410 applications. This does not include either enrollment data or district transcript data, which I do not have. The application data have identifiable information, including name, date of birth, and demographic information.

While I do not have individual-level data on the actual enrollment in the receiving districts, San Mateo and Santa Clara County provided records of student attrition for the 2012-2013 school year and the proximate reason students left the transfer program. The

\footnotetext{
${ }^{7}$ This is possible because a district like Palo Alto opts raises more in local property taxes than they would receive from the state. The district opts out of most state funding in favor of local financing primarily through property taxes.

${ }^{8}$ Note that Palo Alto is a unified school district serving grades K-12, which implies that per-pupil spending numbers are not directly comparable to Ravenswood.
} 
2012-2013 school year does not cover students studied in this paper but it may be informative nonetheless. Among 1,128 students participating in the program throughout all grade levels and districts in that school year, 58 students left the transfer program (4.7\%). The most commonly cited reasons for leaving are moving (28 students), never enrolled (10 students), other (14 students) and returned to Ravenswood City School District (6 students). San Mateo County also has information on aggregate enrollment in more recent years. Based on these data, the first-year enrollment rate conditional on receiving an offer was $94 \%$ in 2011. From 2011 to 2012, kindergarten cohorts between 2003-2004 and the 2007-2008 experienced between two and four percentage point attrition. Assuming four percent annual attrition after a 94\% initial enrollment rate, a cohort of students receiving an offer to enroll in Palo Alto Unified School District remains there for 9 years on average.

The data also do not have information on student gender. Student gender is therefore inferred. Three independent raters marked students as female, male or uncertain based only on each student's first name. If two or more of the raters agreed on male or female, that mark is imputed as a student's gender. Otherwise gender is coded as 0 with an indicator variable for "uncertain." $6 \%$ of the sample is marked as uncertain.

Using names and birth dates from the applications, students are linked to National Student Clearinghouse data. National Student Clearinghouse data have information on college attended, length of enrollment, enrollment status, and degree obtained for more than 3,600 and $98 \%$ of all students in public and private institutions across the United States. Importantly, community colleges local to the sample are in the National Student Clearinghouse data as well. This information is supplemented by classifying colleges into selectivity tiers defined by Barron's Profile of American Colleges.

Restricting the sample to students age 16 or older at the time data were linked to the college outcomes in the spring of 2015, there are 1,493 applications - 1,383 students. This restriction allows for coverage of dual enrollment students as well. Dual enrollment implies students are enrolled in a college-level course at the same time as taking a high school course. 
Figure 2 shows the distribution of age among applicants in the sample. $72 \%$ of the sample is age 18 or older at the time data were merged to college outcomes.

Data on arrest records come from United Reporting, a private firm that obtains public arrest records through agreements with law enforcement agencies across California as well as freedom-of-information-act requests. Arrests after the age of 18 are public record. These records cover all but three of California's 58 counties. The three counties not covered are in rural areas far from where the program takes place and they represent less than $1 \%$ of the entire population of California. ${ }^{9}$ Application data are matched to arrest records using full name and birth date. ${ }^{10}$ There are 1,205 students aged 18 or over at the time of the data merge.

The arrest records also document the arrest codes, which describe the ostensible reason an individual was arrested. The former are coded into non-exclusive indicators for propertyrelated offenses (vandalism and theft), drug-related offenses (possession or sale of drugs) and violent offenses (assault or battery). Other offenses typically indicate driving with a suspended license. For $88 \%$ of the arrests I can also determine the city in which the arrest occurred as well.

Lastly, voting outcomes are from California administrative data. These data record whether an individual voted, their voting history in the past seven elections, whether an individual registered to vote for the 2012 election as well the individual's name and birth date. Application data are therefore matched using name and birth date to the voting record information. There are 675 students eligible for voter registration by the 2012 presidential elections.

Table 3 summarizes the data. Most applicants are Hispanic or Black, followed by AsianPacific Islander. The percent of students who have ever enrolled in college is $39 \%$, most of whom enroll in two-year public colleges. Some students attend both private and public

\footnotetext{
${ }^{9}$ The counties not covered in the data are Modoc County, Sierra County and Siskiyou County.

${ }^{10}$ Specifically, students are matched using exact birth date but a "fuzzy," Soundex matching algorithm for matching first and last names. Middle or second names are omitted.
} 
colleges and both two-year and four-year colleges at various points in time. Unconditional on enrollment, $27 \%$ of students persist through three or more semesters of college. I also define "transfer" as an indicator for whether a student first enrolled in a two-year college and then enrolled in a four-year college, which occurs for $7 \%$ of the sample.

Roughly $9 \%$ percent of the sample has been arrested at some point after the age of 18 . Most arrests fall in the "other" category, followed by property and drug-related arrests. Males are more likely to be arrested than female students; $11 \%$ of male students have been arrested while $6 \%$ of female students have been arrested.

\section{B Empirical Strategy}

I measure the impact of the desegregation program by estimating the effect of a transfer offer on college outcomes. I study the effect of an offer, which is an Intent-to-Treat (ITT) effect, because I do not have detailed enrollment data.

While district preferences and sibling status fully determine the probability of admission, a completely saturated model yields many more parameters than observations. To reduce dimensionality, I simulate 200,000 lotteries to generate admission probabilities for each applicant, as do Abdulkadiroglu et al. (2015) to estimate the effects of charter schools in Denver. Conditioning on the probability of admission to each district is sufficient to eliminate selection bias (Rosenbaum and Rubin, 1983). To account for heterogeneous treatment effects by district, I estimate separate district effects conditioned on probabilities of admission, compute the weighted average of effects according to enrollment shares, and conduct hypothesis tests based on this statistic. The estimating equation is as follows:

$$
y_{i}=\beta_{0}+\operatorname{Dist}_{i} \beta_{1}+\mathbf{A d m i s s i o n}_{i} \beta_{2}+\mathbf{X}_{i} \beta_{3}+\varepsilon_{i}
$$

Where Dist $_{i}$ is a vector of district assignments and Admission $_{i}$ is a vector of associated admission probabilities for each applicant. $\mathbf{X}_{i}$ is a vector of controls, entered separably, for 
applicants' race, gender and age. Inference is conducted using conventional, robust standard errors as in Abdulkadiroglu et al. (2015).

Abdulkadiroglu et al. (2015) note that simulated propensity scores tend to take on more distinct values than the actual score. As a robustness check, they recommend considering various rounded estimates of the score and non-parametrically controlling for these probabilities by using dummy variables for each value it takes on. I conduct this analysis in the section on robustness.

The lottery-based assignment should ensure that those who receive offers are similar, on average, to those who do not receive offers. Table 4 provides evidence that participants' race, gender and age is balanced across lottery winners and losers. Distance to the school district could be a strong predictor of program participation, so I calculate applicants' distance from the Palo Alto Unified School District (measured in miles) as well. There are neither large nor significant differences across lottery winners and losers. A joint test of these variables as predictors of receiving any offer has a p-value equal to 0.616.

\section{Results}

\section{A College Enrollment Outcomes}

The main effects of the offer to transfer on college outcomes are shown in Table 5. The top row shows estimates without controls and the lower panel adds controls for race. Overall, the offer increases the probability of attending college by 10 percentage points. This effect is not sensitive to the addition of controls for race and gender. All remaining tables of results are shown with controls.

The enrollment effect is concentrated within two-year, public colleges. There is no effect on attending either four-year colleges or private colleges. ${ }^{11}$ In terms of persistence, there is a 6 to 7 percentage point impact on the likelihood students attend three or more semesters of

\footnotetext{
${ }^{11}$ There is also no effect on attending four-year public colleges.
} 
college, which is significant at the $10 \%$ level. Though not shown, students are highly likely to persist two or more semesters, which is statistically significant at the $5 \%$ level.

Table 6 explores important heterogeneity in the results. This table shows the results of splitting the sample by race and gender and re-estimating the effects on college enrollment. Panel A shows effects for Black students. These effects show a similar pattern to the overall results, but are muted in magnitude. For instance, the effect on enrollment is smaller at 7 percentage points and the effect on persistence is slightly negative.

Panel B shows that effects are for Hispanic students more in line with the overall results, which is not surprising given the results above and because Hispanic student are the largest demographic group in the sample. Hispanic students are 9 percentage points more likely to enroll in college.

Panels $\mathrm{C}$ and $\mathrm{D}$ show the starkest contrasting results, which are by gender. The effects are concentrated among male students (Panel D). For males, the impact is large and significant across all college-enrollment outcomes, including attendance at a private university. College enrollment increases by 13 percentage points. Attendance at four-year colleges is 7 percentage points and significant at the $5 \%$ level. The enrollment impact implies a $33 \%$ increase over mean college attendance at age 18 for males.

There is a smaller (5 percentage point) effect on female college attendance overall (Panel C). All coefficients are not significant and generally smaller than the other results. This implies that the offer to transfer districts substantially closes the gender gap in college attendance. For context, the regression-adjusted enrollment gap between male and female students in the sample is 15 percentage points in favor of female students.

There is little evidence of an overall impact on college selectivity. Panel A of Table 7 shows the effects of the transfer offer on indicators of selectivity, which are ordered with "most competitive" as the most selective and "competitive" schools as less selective. There is a slight shift from attending "highly competitive" schools to "very competitive" schools. However, most of the schools students attend are less selective and do not fit into any of 
these categories, and there is no overall effect on selectivity (Panel B, column 1). Nor are there differential effects by race; all coefficients are small and not significant, though there is some evidence male students attend more selective schools.

Given the effects on students attending community colleges, there is a potential these students go on to transfer to four-year institutions. Roughly 9 percent of students aged 18 and older transfer in this fashion in the data. However, there is no effect either overall or for any demographic subgroup on the likelihood of attending a two-year college followed by a four-year college (Table 8).

\section{B Arrest Outcomes}

Table 9 shows the effects of a transfer offer on the likelihood of ever being arrested after the age of 18 . There is an increase in the likelihood of arrest by 5 percentage points. The remaining columns show that these effects are primarily driven by arrests related to "other offenses." Based on the descriptions for each arrest code, these other offenses are not drug related or property related or violent. Overwhelmingly the most common of these is driving related, such as driving with a suspended license. There is also a significant positive effect of drug-related arrests, which include both possession and sale.

The point estimates for violent and property-related arrests are near zero and not significant, though there is heterogeneity in the latter, which is discussed below. Moreover, there is no effect on the number arrests, which implies that the program causes an increase in arrest on the extensive margin, and particularly for non-violent offenses and non-property related offenses.

The heterogeneity in effects is largely in line with the heterogeneity found for college enrollment. Table 10 shows the most significant departure is that Black students experience the largest positive increase in arrests (significant at the $10 \%$ level). Though the results lack precision, this is primarily accounted for by increases in "other"-related offenses.

Again, there are small effects for female students, and large, positive effects on male 
students. Masked in the overall effects on arrests, there is a statistically significant, positive effect on property-related arrests for male students, which is offset by negative effect on these arrests for female students. Similar to the overall results however, the largest reason for arrest fits into the "other" category.

\section{Civic Participation Outcomes}

Lastly, there are small effects on the likelihood of registering to vote or voting. The first two columns in Panel A of Table 11 shows the results for the entire sample. The effect on registering to vote is 4 percentage points and the effect on voting is 1 percentage point. Neither effect is statistically insignificant.

If the positive effects on college enrollment reflect positive effects in other domains such as voting, larger impacts would be expected for male students. There are indeed larger and marginally significant effects for males. There are opposing, though not significant, effects female students. The point estimates are all close to zero for Hispanic and Black students. These subgroup results are only suggestive however as much of the sample was too young to be eligible to either register to vote or vote in the 2012 election.

\section{Robustness}

Abdulkadiroglu et al. (2015) note that simulated propensity scores tend to take on more distinct values than the actual score and suggest considering various rounded estimates of the score. As a robustness check, they suggest non-parametrically controlling for these probabilities by using dummy variables for each value the scores takes on. Table A.1 presents the main results with scores rounded to either the nearest tenth, hundredth, or thousandth in Panels A, B and C respectively. The magnitudes are consistent across specifications and all results remain significant at the $5 \%$ level, though the standard errors do increase as the controls become more flexible.

Table A.2 looks at differential impacts by district for the main outcomes. Unsurprisingly 
given its enrollment share and family preferences, the results for Palo Alto largely mirror the results overall. The effects on college enrollment and arrests are particularly large for Belmont-Redwood Shores and San Carlos, respectively. None of the patterns or significance of the results is significantly altered if these districts are excluded from each of these analyses (results available upon request).

\section{E Discussion}

The impacts are positive on college attendance though these overall positive effects on college outcomes mask significant heterogeneity. Female students receive less benefit from the transfer program in terms of college enrollment in contrast to male students, who experience large gains in college enrollment.

Given that these impacts are concentrated in two-year colleges, one question is whether these meaningfully could affect earnings. Jepsen et al. (2014) find that degrees or diplomas from community colleges result in a $\$ 1,500$ increase in quarterly earnings for men. Similarly, Stevens et al. (2014) find earnings returns to a degree ranging from $10 \%$ to $20 \%$ for males. Lastly, Belfield and Bailey (2011) review the evidence on the returns to community college attendance, which shows a $9 \%$ earnings return even to credits that do not lead to a degree.

These enrollment results contrast with the results of random assignment studies some fifty years ago, which examine short-run outcomes and demonstrate small or negligible impact of desegregation on academic outcomes (Cook, 1984). One obvious potential source for this difference is disparity in time periods between the studies in Cook (1984) and the analysis presented here. A second factor may be that interventions occurring early in childhood can have effects on important long-run outcomes despite the fact that short-run cognitive impacts fade (Duncan and Magnuson, 2013). This is the case for programs such as Perry Preschool, Head Start and Nurse Family Partnerships (Currie and Thomas, 1995; Deming, 2009; Heckman et al., 2013; Olds, 2006), and could be the case for the transfer program as well. Students transfer relatively early in childhood, albeit at slightly older ages than 
children participating in the programs mentioned above.

The school-integration-transfer effects are not directly comparable to charter-school and school-choice impacts for several reasons. The potential enrollment length in this context is much longer and the timing begins at an earlier age than typically studied in charter schools, which usually begin in middle or high school. With these caveats in mind, the effects found here are larger. Dobbie and Fryer (2013) report an ITT effect on college attendance equal to 5 percentage points, which primarily shifts students from attendance at two-year schools to attendance at four-year schools. Angrist et al. (2013) show a similar size and pattern of results for college outcomes.

In general, there seems to be no consistent pattern to the heterogeneous effects of schools or neighborhoods on academic outcomes. Angrist et al. (2013) find slightly stronger effects for males on the likelihood of attending any college and similar effects across gender for fouryear college attendance, though the disparity is not nearly the size found in this transfer program. Deming et al. (2014) find overall college-enrollment effects of receiving an offer to attend a first-choice school, which stem from the gains accrued by female students.

Recent research has studied the longer-run impacts of the Moving to Opportunity project on children. For youth aged 13 to 20, a similar age group to the youth studied in the transfer program, Gennetian et al. (2012) find there was no impact on math and reading assessments. Chetty et al. (2016) find a 2.5 percentage point increase in on-time college attendance for families with children under the age of 13 who participated in MTO. Interestingly, Chetty, Hendren and Katz do not find differential impacts for gender, which contrasts with the shorter-run impacts which generally found more positive effects for female children and than male children (Kling et al., 2007).

There has been less evidence using experimental variation in schooling to study voting behaviors. Sondheimer and Green (2010) analyze three education-related interventions on voting behaviors and find 2-9 percentage point reduced-form impacts on the likelihood of voting, depending on the intervention. They do not analyze heterogeneous effects. I find 
small, insignificant effects on voting overall, though offsetting effects for male and female students. More conclusive results would be found by tracking voting behaviors in the upcoming 2016 presidential election.

The positive effects on college enrollment are dampened by the increased likelihood of arrest. A closer look at the arrest codes reveals a bit more information about the nature of these arrests. In particular, it is instructive to break down the "other"-related arrests to a finer level. Conditional arrest, just over half (52\%) of all students have an arrest in this latter category. The bulk (40\%) of these "other" arrests have some relation to drivingrelated offenses. For instance, driving with a suspended license, driving under the influence of alcohol or driving at a high speed. Breaking this category down further, another $10 \%$ (conditional on arrest) of offenses are for being "drunk" in public, according to the arrest code.

To break down the treatment effects further, I create an arrest variable that is a zero for any arrest solely related to these two categories and a one for an arrest that has any relation to drugs, property or violence. Table A.3 shows the overall effect on arrests, which drops by roughly $50 \%$ compared to the previous results and becomes marginally insignificant $(\mathrm{p}$-value $=0.12)$. The effect for female students is now zero, and the effect for male students is $40 \%$ smaller. In results not shown, the remainder of arrests for male students are primarily driven by property-related offenses.

Given that a significant portion of the arrests are caused by driving and intoxicationrelated offenses, this may be caused by greater police resources to address these potential crimes compared to where non-transfer students travel (Cook and Goss, 1996; Gennetian et al., 2012). Alternatively, there may be discrimination against minority males that increases their likelihood of being stopped relative to students not receiving the transfer offer (Kling et al., 2005). It is difficult to distinguish between these two hypotheses, but I can check if transfer students were more likely to go to a college far away (greater than 15 miles from the Ravenswood City School District) or closer (less than 15 miles away from the Ravenswood 
City School District). The median distance from Ravenswood City School District to the colleges attended by applicants is 28 miles. Table A.4 shows that the bulk of the overall effect and the effects on male students is driven by attendance to colleges farther away, as there little effect on the likelihood of attendance to colleges close by.

Lastly, I also examine where the increase arrests occurred. If arrests correspond to a locational shift of the students, then it is likely that the arrests are in Palo Alto or, given that students attend college farther from home, even outside of Palo Alto and East Palo Alto. I study the effects on an indicator for ever being arrested in Palo Alto, another indicator for ever being arrested in East Palo Alto, and a final indicator for ever being arrested outside of Palo Alto and East Palo Alto. Table A.5 presents the results of this analysis. Column (1) shows that program participants are 2 percentage points more likely to be arrested in Palo Alto. There is no effect on the likelihood of being arrested in East Palo Alto. Column (3) shows that there is another 2 percentage point increase in the likelihood of being arrested outside of Palo Alto and East Palo Alto. Overall, these pattern of effects are consistent with the integration program causing students to traverse areas farther from the Ravenswood area, which possibly exposes them to greater risk of being arrested for non-violent offenses as a result.

\section{Conclusion}

Significant segregation across neighborhoods and schools raises important questions about the effects of neighborhood and school segregation on human-capital development. This paper presents evidence on the effects of a natural experiment that creates random variation in access to higher-resource, low-minority share school districts while approximately holding neighborhood characteristics constant. The impacts on college enrollment are large and significant and benefit male students in particular. The latter experience gains across a range of college-related outcomes: two-year and perhaps four-year enrollment, as well as 
private and public-school enrollment, and persistence through multiple semesters. These results suggest that when segregation impedes access to schools, on the margin there are large, deleterious effects on human-capital outcomes for students often deemed most at risk.

? cites improvements in peer quality and changes in school expectation for achievement as possible mechanisms for integration to increase educational attainment. Interviews with students indicate these mechanisms may play role in this context as well. In a local newspaper interview with two former transfer students, one student recalls a counselor connecting her with a Palo Alto High School graduate currently enrolled in college for guidance (Kenrick, 2012). Other students express pride in doing work "above grade level" (Bischoff, 2014).

However, there is a corresponding increase in the likelihood of arrest concentrated among male students. The modal arrest is for a driving-related offense, which is the type of offense that would be consistent with effects generated by some combination of contextual change and actual behavioral changes induced by the program. I show evidence that the former is likely an important determinant.

The transfer program discussed here is not unique; similar programs exist in Connecticut, Indiana, Massachusetts, Minnesota, Missouri, New York and Wisconsin (Wells et al., 2009). Policies that aim to integrate schools, such as the White House's $\$ 120$ million dollar proposal to incentivize the integration of schools, could reap long-run benefits in college enrollment. However these policies should simultaneously consider programs to mitigate the potential risks for participating students as well. 


\section{References}

Abdulkadiroglu, Atila, Joshua D Angrist, Yusuke Narita, and Parag A Pathak, "Research design meets market design: Using centralized assignment for impact evaluation," Technical Report, National Bureau of Economic Research 2015.

Angrist, Joshua D and Kevin Lang, "Does School Integration Generate Peer Effects? Evidence from Boston's Metco Program," American Economic Review, 2004, 94 (5), 16131634.

Angrist, Joshua D., Sarah R. Cohodes, Susan M. Dynarski, Parag A. Pathak, and Christopher R. Walters, "Stand and Deliver: Effects of Boston's Charter High Schools on College Preparation, Entry, and Choice," Working Paper 19275, National Bureau of Economic Research July 2013.

Belfield, Clive R and Thomas Bailey, "The benefits of attending community college: A review of the evidence," Community College Review, 2011, 39 (1), 46-68.

Billings, Stephen B., David J. Deming, and Jonah Rockoff, "School Segregation, Educational Attainment and Crime: Evidence from the end of busing in CharlotteMecklenburg," The Quarterly Journal of Economics, 2013.

Bischoff, Kendra, "Unpublished Manuscript on the Tinsley Program," 2014.

Booker, Kevin, Brian Gill, Tim Roger Sass, and Ron Zimmer, "Charter High Schools' Effects on Long-Term Attainment and Earnings," Mathematica Policy Research Reports, Mathematica Policy Research 2014.

Card, David and Jesse Rothstein, "Racial segregation and the blackwhite test score gap," Journal of Public Economics, December 2007, 91 (11-12), 2158-2184. 
Chetty, Raj, Nathaniel Hendren, and Lawrence F. Katz, "The Effects of Exposure to Better Neighborhoods on Children: New Evidence from the Moving to Opportunity Experiment," American Economic Review, 2016, 106 (4), 855-902.

Coleman, James S., Sara D. Kelly, and John A. Moore, Trends in School Segregation, 1968-1973, The Urban Institute, Washington, D.C., 1975.

Cook, Philip J and Kristin A Goss, "A selective review of the social-contagion literature," Technical Report, Working paper, Sanford Institute of Policy Studies, Duke University 1996.

Cook, Thomas D, "What have black children gained academically from school desegregation? A review of the metaanalytic evidence," School Desegregation, 1984, pp. 6-42.

Cunha, Flavio and James Heckman, "The Technology of Skill Formation," American Economic Review, 2007, 97 (2), 31-47.

Currie, Janet and Duncan Thomas, "Does Head Start Make a Difference?," The American Economic Review, 1995, 85 (3), 341-364.

Dee, Thomas S, "Are there civic returns to education?," Journal of Public Economics, 2004, 88 (9), 1697-1720.

Deming, David, "Early Childhood Intervention and Life-Cycle Skill Development: Evidence from Head Start," American Economic Journal: Applied Economics, 2009, 1 (3), $111-34$.

Deming, David J., Justine S. Hastings, Thomas J. Kane, and Douglas O. Staiger, "School Choice, School Quality, and Postsecondary Attainment," American Economic Review, 2014, 104 (3), 991-1013. 
Dobbie, Will and Roland Fryer, "The Medium-Term Impacts of High-Achieving Charter Schools on Non-Test Score Outcomes," Working Paper 19581, National Bureau of Economic Research October 2013.

Duncan, Greg J. and Katherine Magnuson, "Investing in Preschool Programs," The Journal of Economic Perspectives, 2013, 27 (2), 109-132.

Fiel, Jeremy E., "Decomposing School Resegregation: Social Closure, Racial Imbalance, and Racial Isolation," American Sociological Review, August 2013, 78 (5), 828-848.

Gennetian, Lisa A, Lisa Sanbonmatsu, Lawrence F Katz, Jeffrey R Kling, Matthew Sciandra, Jens Ludwig, Greg J Duncan, and Ronald C Kessler, "The long-term effects of Moving to Opportunity on youth outcomes," Cityscape, 2012, pp. 137167.

Gould, Eric D, Victor Lavy, and M Daniele Paserman, "Sixty years after the magic carpet ride: The long-run effect of the early childhood environment on social and economic outcomes," The Review of Economic Studies, 2011, p. rdq038.

Guryan, Jonathan, "Desegregation and Black Dropout Rates," American Economic Review, 2004, 94 (4), 919-943.

Hastings, Justine S, Thomas J Kane, and Douglas O Staiger, "Parental preferences and school competition: Evidence from a public school choice program," Technical Report, National Bureau of Economic Research 2005.

Heckman, James and Pedro Carneiro, "Human Capital Policy," Working Paper 9495, National Bureau of Economic Research February 2003.

_, Rodrigo Pinto, and Peter Savelyev, "Understanding the Mechanisms through Which an Influential Early Childhood Program Boosted Adult Outcomes," American Economic Review, 2013, 103 (6), 2052-86. 
Jepsen, Christopher, Kenneth Troske, and Paul Coomes, "The labor-market returns to community college degrees, diplomas, and certificates," Journal of Labor Economics, 2014, 32 (1), 95-121.

Johnson, Rucker C., "Long-run Impacts of School Desegregation \& School Quality on Adult Attainments," Working Paper 16664, National Bureau of Economic Research August 2015.

Jones, Bayinaah, "The Tinsley Case Decision," PhD Dissertation, University of North Carolna at Chapel Hill 2006.

Kenrick, Chris, Beyond Tinsley, Palo Alto Weekly, May 2012.

Kling, Jeffrey R, Jeffrey B Liebman, and Lawrence F Katz, "Experimental analysis of neighborhood effects," Econometrica, 2007, 75 (1), 83-119.

_ , Jens Ludwig, and Lawrence F Katz, "Neighborhood effects on crime for female and male youth: Evidence from a randomized housing voucher experiment," The Quarterly Journal of Economics, 2005, pp. 87-130.

Ludwig, Jens, Greg J Duncan, Lisa a Gennetian, Lawrence F Katz, Ronald C Kessler, Jeffrey R Kling, and Lisa Sanbonmatsu, "Neighborhood effects on the long-term well-being of low-income adults.," Science (New York, N.Y.), September 2012, 337 (6101), 1505-10.

Lutz, Byron, "The End of Court-Ordered Desegregation," American Economic Journal: Economic Policy, 2011, 3 (2), 130-68.

Magre, Jaume, Joan-Josep Vallbé, and Mariona Tomàs, "Moving to suburbia? Effects of residential mobility on community engagement," Urban Studies, 2014, p. 0042098014562532 . 
Milligan, Kevin, Enrico Moretti, and Philip Oreopoulos, "Does education improve citizenship? Evidence from the United States and the United Kingdom," Journal of public Economics, 2004, 88 (9), 1667-1695.

Olds, David L, "The nurse-family partnership: An evidence-based preventive intervention," Infant Mental Health Journal, 2006, 27 (1), 5-25.

Pathak, Parag A, "The mechanism design approach to student assignment," Annu. Rev. Econ., 2011, 3 (1), 513-536.

Reardon, Sean F and Ann Owens, "60 Years After Brown : Trends and Consequences of School Segregation," Annual Review of Sociology, Forthcoming.

Reber, Sarah, "Court-Ordered Desegregation Successes and Failures Integrating American Schools since Brown versus Board of Education," Journal of Human Resources, 2005, 40 (3), 559-590.

_, "School Desegregation and Educational Attainment for Blacks," Journal of Human Resources, 2010, $45(4), 893-914$.

Rivkin, Steven and Finis Welch, "Has school desegregation improved academic and economic outcomes for blacks?," Handbook of the Economics of Education, 2006, 2, 10191049.

Rosenbaum, James E, "Black pioneersdo their moves to the suburbs increase economic opportunity for mothers and children?," Housing Policy Debate, 1991, 2 (4), 1179-1213.

Rosenbaum, Paul R and Donald B Rubin, "The central role of the propensity score in observational studies for causal effects," Biometrika, 1983, 70 (1), 41-55.

Sanbonmatsu, Lisa, Jeffrey R. Kling, Greg J. Duncan, and Jeanne Brooks-Gunn, "Neighborhoods and Academic Achievement: Results from the Moving to Opportunity Experiment," Journal of Human Resources, 2006, XLI (4), 649-691. 
Schwartz, Heather L, "Housing Policy is School Policy," 2010.

Sondheimer, Rachel Milstein and Donald P Green, "Using experiments to estimate the effects of education on voter turnout," American Journal of Political Science, 2010, 54 (1), 174-189.

Stevens, Ann, Michal Kurlaender, and Michel Grosz, "Career technical education and labor market outcomes: evidence from California community colleges," in "Paper presented March," Vol. 14 2014, p. 2014.

Vigdor, Jacob and Jens Ludwig, "Segregation and the black-white test score gap," Technical Report, National Bureau of Economic Research 2007.

Welch, Finis and Andrew Light, New Evidence on School Desegregation., U.S. Commission on Civil Rights, 1987.

Wells, Amy Stuart, Bianca J Baldridge, Jacquelyn Duran, Courtney Grzesikowski, Richard Lofton, Allison Roda, Miya Warner, and Terrenda White, "Boundary Crossing for Diversity, Equity and Achievement," 2009. 
Figure 1: Participating School Districts

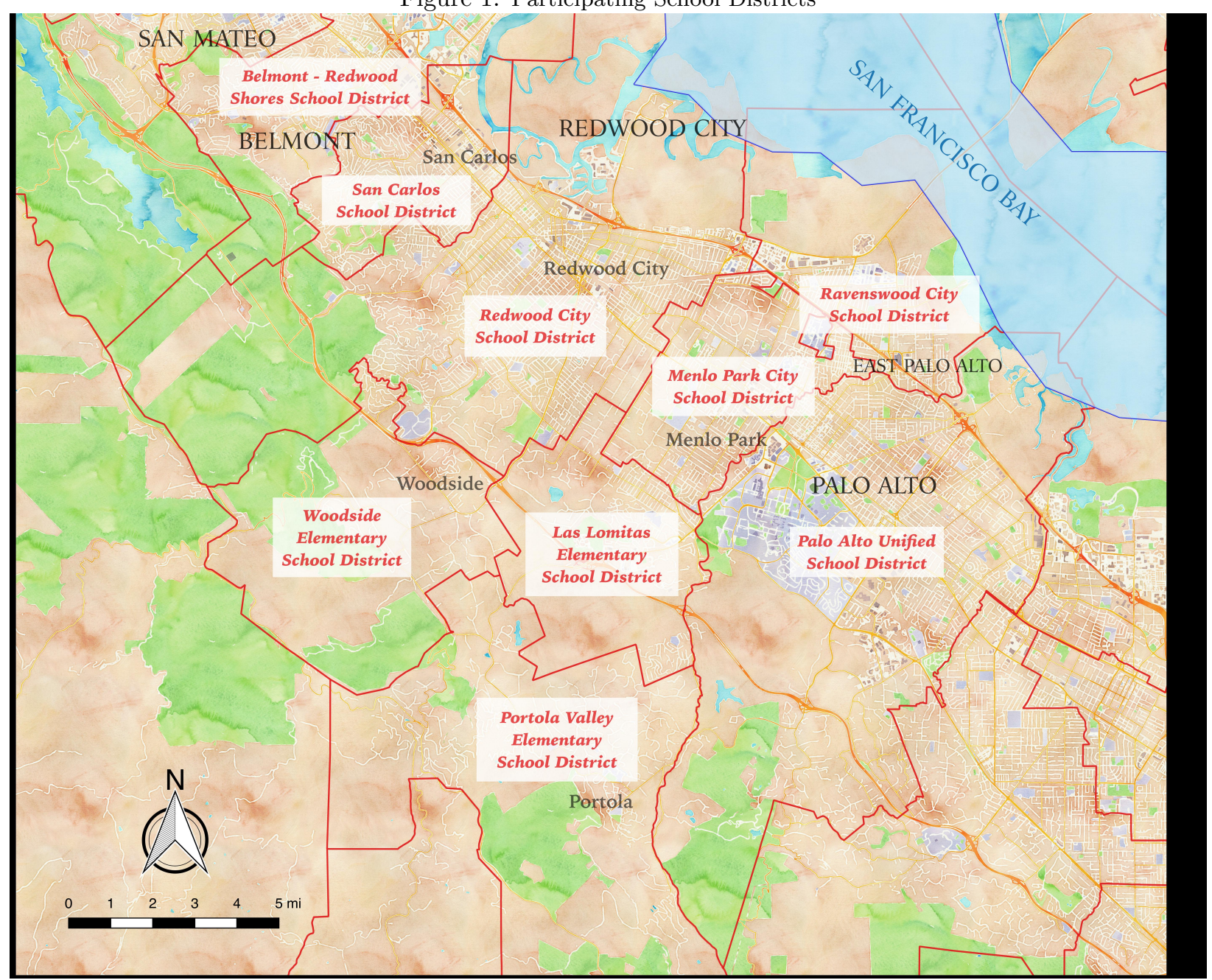

This map shows the geographic location of participating school districts in the California Bay Area. Ravenswood City School District is the sending district. The other districts highlighted with white backgrounds are receiving districts. The shape file for this map comes from the National Center for Education Statistics. 
Figure 2: Distribution of Applicants' Ages

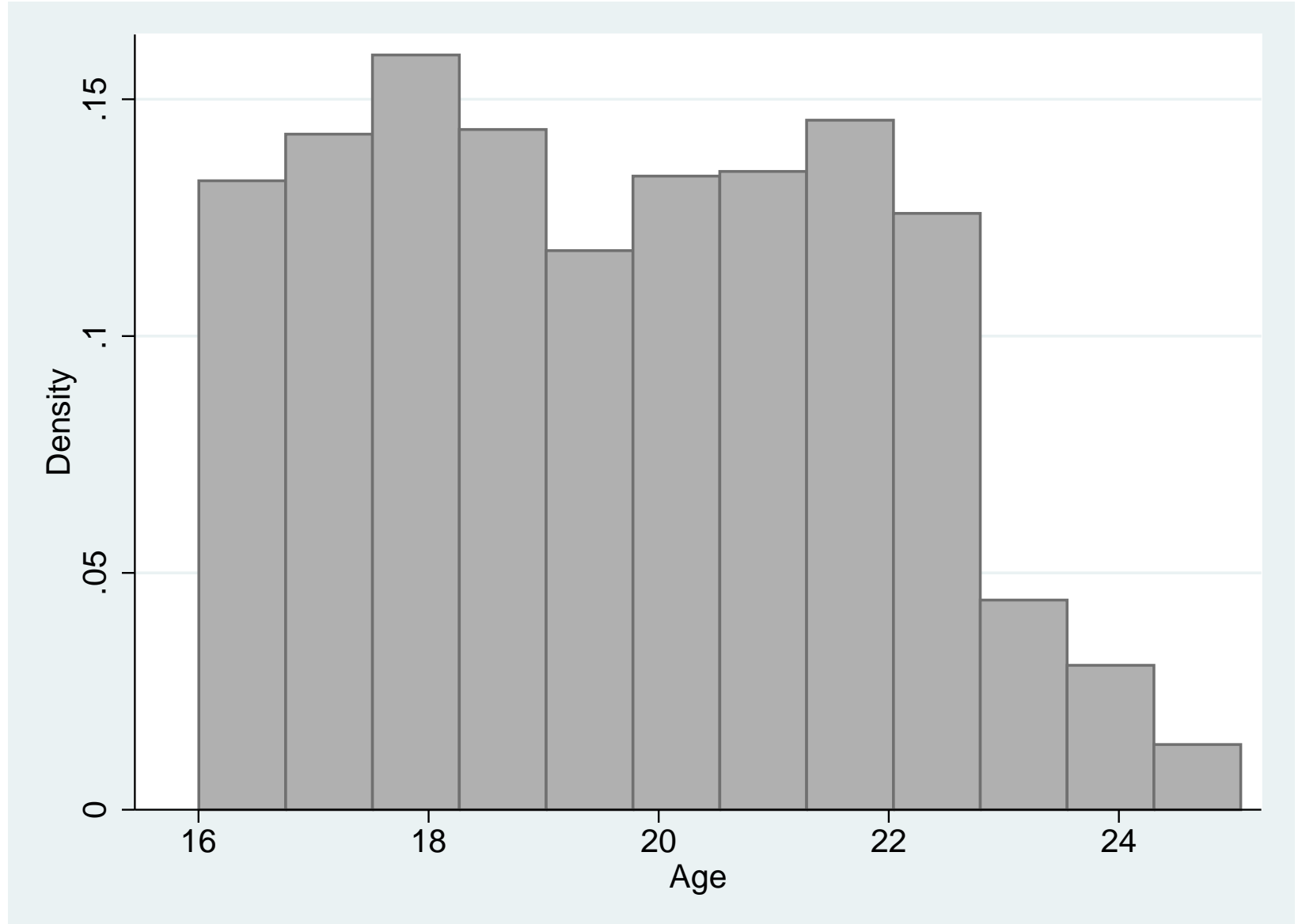

This figure shows the distribution of applicants' ages using application records based on the date application records were merged to college enrollment data. 
Table 1: Distribution of Family Preferences over Districts

\begin{tabular}{|c|c|c|c|c|c|c|c|}
\hline & $1 \mathrm{st}$ & $2 \mathrm{nd}$ & $3 \mathrm{rd}$ & 4 th & 5 th & 6 th & 7 th \\
\hline None & $0 \%$ & $31 \%$ & $56 \%$ & $75 \%$ & $84 \%$ & $87 \%$ & $88 \%$ \\
\hline Belmont-R.S. & $2 \%$ & $2 \%$ & $4 \%$ & $4 \%$ & $4 \%$ & $3 \%$ & $3 \%$ \\
\hline Las Lomitas & $6 \%$ & $7 \%$ & $12 \%$ & $3 \%$ & $2 \%$ & $2 \%$ & $2 \%$ \\
\hline Menlo Park & $16 \%$ & $40 \%$ & $7 \%$ & $2 \%$ & $0 \%$ & $1 \%$ & $0 \%$ \\
\hline Palo Alto & $67 \%$ & $14 \%$ & $5 \%$ & $1 \%$ & $0 \%$ & $0 \%$ & $0 \%$ \\
\hline Portola Valley & $3 \%$ & $2 \%$ & $4 \%$ & $4 \%$ & $3 \%$ & $3 \%$ & $3 \%$ \\
\hline San Carlos & $4 \%$ & $3 \%$ & $5 \%$ & $5 \%$ & $4 \%$ & $4 \%$ & $1 \%$ \\
\hline \multirow[t]{2}{*}{ Woodside } & $2 \%$ & $2 \%$ & $8 \%$ & $6 \%$ & $4 \%$ & $1 \%$ & $2 \%$ \\
\hline & $\begin{array}{c}\text { Belmont- } \\
\text { Redwood Shores }\end{array}$ & $\begin{array}{c}\text { Las } \\
\text { Lomitas }\end{array}$ & Menlo Park & Palo Alto & $\begin{array}{l}\text { Portola } \\
\text { Valley }\end{array}$ & San Carlos & Woodside \\
\hline Seats & 31 & 12 & 24 & 60 & 8 & 26 & 5 \\
\hline
\end{tabular}


Table 2: District and Household-Level Summary Statistics

\begin{tabular}{|c|c|c|c|c|c|}
\hline \multirow[t]{2}{*}{ Panel A. } & \multicolumn{5}{|c|}{ District Information } \\
\hline & $\underline{\text { Student/Teacher }}$ & $\underline{\text { Special Ed. }}$ & $\underline{\mathrm{LEP}}$ & $\underline{\text { Spending/Pupil }}$ & $\underline{\text { Ave. Percentile }}$ \\
\hline Ravenswood & 19.2 & $7 \%$ & $65 \%$ & 7,413 & 28 \\
\hline Belmont-Redwood Shores & 17.9 & $10 \%$ & $4 \%$ & 7,196 & 72 \\
\hline Las Lomitas & 16.8 & $10 \%$ & $6 \%$ & 9,151 & 90 \\
\hline Menlo Park & 18.0 & $11 \%$ & $6 \%$ & 12,014 & 85 \\
\hline Palo Alto & 17.7 & $11 \%$ & $5 \%$ & 11,982 & 87 \\
\hline Portola Valley & 15.8 & $13 \%$ & $1 \%$ & 10,840 & 89 \\
\hline San Carlos & 20.6 & $7 \%$ & $2 \%$ & 12,643 & 71 \\
\hline Woodside & 13.8 & $8 \%$ & $4 \%$ & 15,876 & 88 \\
\hline \multirow[t]{2}{*}{ Panel B. } & \multicolumn{5}{|c|}{ Race $\backslash$ Ethnicity Information } \\
\hline & White & Black & $\underline{\text { Asian }}$ & $\underline{\text { Hispanic }}$ & $\underline{\mathrm{A} / \mathrm{PI}}$ \\
\hline Ravenswood & $1 \%$ & $24 \%$ & $1 \%$ & $64 \%$ & $10 \%$ \\
\hline Belmont-Redwood Shores & $64 \%$ & $3 \%$ & $16 \%$ & $11 \%$ & $1 \mathrm{t} \%$ \\
\hline Las Lomitas & $80 \%$ & $3 \%$ & $9 \%$ & $7 \%$ & $1 \%$ \\
\hline Menlo Park & $78 \%$ & $4 \%$ & $6 \%$ & $8 \%$ & $3 \%$ \\
\hline Palo Alto & $68 \%$ & $5 \%$ & $19 \%$ & $7 \%$ & $1 \%$ \\
\hline Portola Valley & $87 \%$ & $3 \%$ & $5 \%$ & $4 \%$ & $2 \%$ \\
\hline San Carlos & $80 \%$ & $2 \%$ & $6 \%$ & $9 \%$ & $1 \%$ \\
\hline Woodside & $85 \%$ & $2 \%$ & $3 \%$ & $9 \%$ & $1 \%$ \\
\hline Panel C. & \multicolumn{5}{|c|}{ Household Information } \\
\hline
\end{tabular}

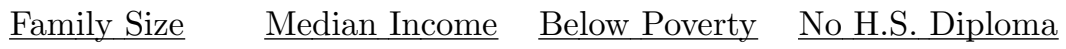

$\begin{array}{lcccc}\text { Ravenswood } & \mathbf{3 . 8} & \mathbf{\$ 4 5 , 5 7 3} & \mathbf{2 0 \%} & \mathbf{5 4 \%} \\ \text { Belmont-Redwood Shores } & 2.3 & \$ 87,267 & 2 \% & 5 \% \\ \text { Las Lomitas } & 2.4 & \$ 125,360 & 0 \% & 4 \% \\ \text { Menlo Park } & 2.3 & \$ 100,827 & 5 \% & 3 \% \\ \text { Palo Alto } & 2.3 & \$ 87,549 & 4 \% & 4 \% \\ \text { Portola Valley } & 2.7 & \$ 162,027 & 2 \% & 3 \% \\ \text { San Carlos } & 2.4 & \$ 87,459 & 3 \% & 5 \% \\ \text { Woodside } & 2.7 & \$ 149,062 & 0 \% & 7 \%\end{array}$

Percentile scores and ethnicity are from the California Department of Education data from the year 2000 . The average percentile score is the average of grade five math and reading percentile scores. The remaining information in Panel A is from the Common Core of Data. All summary statistics in Panel $\mathrm{C}$ are drawn from the year 2000 census. 
Table 3: Applicant Summary Statistics

\begin{tabular}{|c|c|c|}
\hline Variable & Mean & Observations \\
\hline \multicolumn{3}{|l|}{ Demographics } \\
\hline $\begin{array}{l}\text { Age } \\
\text { Female } \\
\text { Black } \\
\text { Hispanic } \\
\text { Asian/Pacific Islander }\end{array}$ & $\begin{array}{c}20 \\
52 \% \\
27 \% \\
59 \% \\
12 \%\end{array}$ & $\begin{array}{l}1,380 \\
1,294 \\
1,380 \\
1,380 \\
1,380\end{array}$ \\
\hline \multicolumn{3}{|l|}{ College Enrollment } \\
\hline $\begin{array}{l}\text { Ever enrolled } \\
4 \text {-year ever enrolled } \\
2 \text {-year ever enrolled } \\
\text { Persistence }\end{array}$ & $\begin{array}{l}39 \% \\
17 \% \\
31 \% \\
34 \%\end{array}$ & $\begin{array}{l}1,380 \\
1,380 \\
1,380 \\
1,380\end{array}$ \\
\hline $\begin{array}{l}\text { Private school ever enrolled } \\
\text { Public school ever enrolled } \\
\text { Top three selectivity tiers } \\
\text { Transfer }\end{array}$ & $\begin{array}{c}7 \% \\
36 \% \\
5 \% \\
7 \%\end{array}$ & $\begin{array}{l}1,380 \\
1,380 \\
1,380 \\
1,380\end{array}$ \\
\hline \multicolumn{3}{|l|}{$\underline{\text { Arrest }}$} \\
\hline $\begin{array}{l}\text { Ever Arrested } \\
\text { Property Offense } \\
\text { Drug Offense } \\
\text { Violent Offense } \\
\text { Other Offense }\end{array}$ & $\begin{array}{l}8.7 \% \\
2.5 \% \\
2.0 \% \\
1.7 \% \\
4.6 \%\end{array}$ & $\begin{array}{l}1,205 \\
1,205 \\
1,205 \\
1,205 \\
1,205\end{array}$ \\
\hline \multicolumn{3}{|l|}{ Voting } \\
\hline $\begin{array}{l}\text { Registered } \\
\text { Voted }\end{array}$ & $\begin{array}{l}34 \% \\
23 \%\end{array}$ & $\begin{array}{l}675 \\
675\end{array}$ \\
\hline
\end{tabular}

\footnotetext{
Data come from application data and the National Student Clearinghouse. Top Three Selectivity Tiers are college selectivity categories defined by Barron's Profiles of American Colleges. Transfer is defined as any enrollment in community college prior to attending a four-year college. Gender is inferred from student names. These numbers are for unique, eligible applicants age 16 and older in Fall 2013. Arrest records are from United Reporting and the sample consists of students who were aged 18 and older at the time the data were merged. Voting records are from public California administrative data for any person who registered to vote in the 2012 presidential election.
} 
Table 4: Balance at Baseline

\begin{tabular}{lllllll}
\hline \hline & Age & Female & Black & Hispanic & A/PI & Distance \\
\hline \multirow{2}{*}{ Offer } & & & & & & \\
& 0.049 & 0.028 & -0.035 & 0.014 & 0.000 & 0.050 \\
& $(0.197)$ & $(0.042)$ & $(0.036)$ & $(0.041)$ & $(0.027)$ & $(0.057)$ \\
Joint-Test P Value & 0.616 & & & & & \\
Observations & 1,380 & 1,380 & 1,380 & 1,380 & 1,380 & 1,380 \\
& & & & & & \\
\hline \hline
\end{tabular}

Regressions control for district admission probabilities. See text for exact specification. Data come from program applications and the National Student Clearinghouse for eligible applicants age 15 and older. Robust standard errors shown in parentheses.

$* * * \mathrm{p}<0.01, * * \mathrm{p}<0.05, * \mathrm{p}<0.1$

Table 5: College Outcomes

\section{College Enrollment Outcomes}

Enrollment Any 2 yr. Any 4 yr. Public $\underline{\text { Private }}$ Persistence

No Controls

Offer

$$
\begin{array}{cccccc}
0.101^{* * *} & 0.074^{*} & 0.028 & 0.092^{* *} & 0.015 & 0.063^{*} \\
(0.039) & (0.038) & (0.028) & (0.039) & (0.019) & (0.036)
\end{array}
$$

With Controls

Offer

$\begin{array}{cccccc}0.096^{* * *} & 0.067^{* *} & 0.030 & 0.087^{* * *} & 0.016 & 0.061^{*} \\ (0.034) & (0.033) & (0.028) & (0.034) & (0.019) & (0.032)\end{array}$

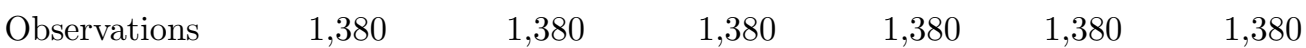

All regressions control for district admission probabilities and additional controls are race, gender, distance to Palo Alto and age. See text for exact specification. Data come from program applications and the National Student Clearinghouse for eligible applicants age 16 and older. Robust standard errors shown in parentheses.

$* * * \mathrm{p}<0.01, * * \mathrm{p}<0.05, * \mathrm{p}<0.1$ 
Table 6: Main Effects: Heterogeneity by Demographics

\begin{tabular}{|c|c|c|c|c|c|c|}
\hline \multirow[t]{2}{*}{ Panel A. } & \multicolumn{6}{|c|}{ College Outcomes: Black Students } \\
\hline & $\underline{\text { Enrollment }}$ & Any 2 yr. & Any 4 yr. & $\underline{\text { Public }}$ & $\underline{\text { Private }}$ & $\underline{\text { Persistence }}$ \\
\hline Offer & $\begin{array}{c}0.066 \\
(0.071)\end{array}$ & $\begin{array}{c}0.024 \\
(0.074)\end{array}$ & $\begin{array}{l}-0.043 \\
(0.064)\end{array}$ & $\begin{array}{c}0.059 \\
(0.073)\end{array}$ & $\begin{array}{c}0.027 \\
(0.045)\end{array}$ & $\begin{array}{l}-0.036 \\
(0.074)\end{array}$ \\
\hline Observations & 372 & 372 & 372 & 372 & 372 & 372 \\
\hline \multirow[t]{2}{*}{ Panel B. } & \multicolumn{6}{|c|}{ College Outcomes: Hispanic Students } \\
\hline & $\underline{\text { Enrollment }}$ & Any 2 yr. & Any 4 yr. & $\underline{\text { Public }}$ & $\underline{\text { Private }}$ & $\underline{\text { Persistence }}$ \\
\hline Offer & $\begin{array}{c}0.089^{* *} \\
(0.039)\end{array}$ & $\begin{array}{c}0.078^{* *} \\
(0.039)\end{array}$ & $\begin{array}{c}0.044 \\
(0.032)\end{array}$ & $\begin{array}{c}0.093^{* *} \\
(0.040)\end{array}$ & $\begin{array}{c}0.005 \\
(0.022)\end{array}$ & $\begin{array}{l}0.064^{*} \\
(0.037)\end{array}$ \\
\hline Observations & 819 & 819 & 819 & 819 & 819 & 819 \\
\hline \multirow[t]{2}{*}{ Panel C. } & \multicolumn{6}{|c|}{ College Outcomes: Female Students } \\
\hline & $\underline{\text { Enrollment }}$ & Any 2 yr. & Any 4 yr. & $\underline{\text { Public }}$ & $\underline{\text { Private }}$ & Persistence \\
\hline Offer & $\begin{array}{c}0.050 \\
(0.047)\end{array}$ & $\begin{array}{c}0.041 \\
(0.049)\end{array}$ & $\begin{array}{l}-0.016 \\
(0.043)\end{array}$ & $\begin{array}{c}0.064 \\
(0.048)\end{array}$ & $\begin{array}{l}-0.026 \\
(0.035)\end{array}$ & $\begin{array}{c}0.025 \\
(0.047)\end{array}$ \\
\hline Observations & 666 & 666 & 666 & 666 & 666 & 666 \\
\hline Panel D. & \multicolumn{6}{|c|}{ College Outcomes: Male Students } \\
\hline & $\underline{\text { Enrollment }}$ & Any 2 yr. & Any 4 yr. & $\underline{\text { Public }}$ & $\underline{\text { Private }}$ & Persistence \\
\hline Offer & $\begin{array}{c}0.132^{* * *} \\
(0.047)\end{array}$ & $\begin{array}{l}0.087^{*} \\
(0.046)\end{array}$ & $\begin{array}{c}0.071^{* *} \\
(0.036)\end{array}$ & $\begin{array}{c}0.107^{* *} \\
(0.048)\end{array}$ & $\begin{array}{c}0.050^{* * *} \\
(0.019)\end{array}$ & $\begin{array}{c}0.094^{* *} \\
(0.043)\end{array}$ \\
\hline Observations & 714 & 714 & 714 & 714 & 714 & 714 \\
\hline
\end{tabular}

Regressions control for district admission probabilities, race, gender and age. See text for exact specification. Data come from transfer applications and the National Student Clearinghouse for eligible applicants age 16 and older. Robust standard errors shown in parentheses.

$* * * \mathrm{p}<0.01, * * \mathrm{p}<0.05, * \mathrm{p}<0.1$ 
Table 7: College Selectivity

\begin{tabular}{|c|c|c|c|c|}
\hline \multirow[t]{2}{*}{ Panel A. } & \multicolumn{4}{|c|}{ College Selectivity } \\
\hline & $\underline{\text { Most Competitive }}$ & $\underline{\text { Highly Competitive }}$ & Very Competitive & Competitive \\
\hline Offer & $\begin{array}{c}0.001 \\
(0.011)\end{array}$ & $\begin{array}{l}-0.014 \\
(0.009)\end{array}$ & $\begin{array}{c}0.017^{* *} \\
(0.007)\end{array}$ & $\begin{array}{c}0.025 \\
(0.020)\end{array}$ \\
\hline Panel B. & \multicolumn{4}{|c|}{ College Selectivity by Demographic } \\
\hline & Top Three Tiers & Top Three Tiers & Top Three Tiers & Top Three Tiers \\
\hline Offer & $\begin{array}{c}0.003 \\
(0.015)\end{array}$ & $\begin{array}{c}0.006 \\
(0.017)\end{array}$ & $\begin{array}{c}0.003 \\
(0.028)\end{array}$ & $\begin{array}{l}0.033^{*} \\
(0.020)\end{array}$ \\
\hline Offer $\times$ Black & & $\begin{array}{l}-0.017 \\
(0.039)\end{array}$ & & \\
\hline Offer $\times$ Hispanic & & & $\begin{array}{l}-0.002 \\
(0.034)\end{array}$ & \\
\hline Offer $\times$ Female & & & & $\begin{array}{c}-0.066^{* *} \\
(0.033)\end{array}$ \\
\hline Observations & 1380 & 1380 & 1380 & 1380 \\
\hline
\end{tabular}

Regressions control for district admission probabilities, race, gender and age. See text for exact specification. Data come from transfer applications and the National Student Clearinghouse for eligible applicants age 16 and older. Selectivity tiers are from Baron's. Robust standard errors shown in parentheses.

*** $\mathrm{p}<0.01,{ }^{* *} \mathrm{p}<0.05,{ }^{*} \mathrm{p}<0.1$ 
Table 10: Arrest Effect Heterogeneity by Demographics

\begin{tabular}{|c|c|c|c|c|c|c|}
\hline \multirow[t]{2}{*}{ Panel A. } & \multicolumn{6}{|c|}{ Arrest Outcomes: Black Students } \\
\hline & $\underline{\text { Ever Arrested }}$ & $\underline{\text { Arrests }}$ & $\underline{\text { Violent }}$ & $\underline{\text { Property }}$ & $\underline{\text { Drugs }}$ & $\underline{\text { Other }}$ \\
\hline Offer & $\begin{array}{l}0.082^{*} \\
(0.046)\end{array}$ & $\begin{array}{l}-0.103 \\
(0.290)\end{array}$ & $\begin{array}{c}0.022 \\
(0.017)\end{array}$ & $\begin{array}{c}0.010 \\
(0.037)\end{array}$ & $\begin{array}{c}0.002 \\
(0.011)\end{array}$ & $\begin{array}{c}0.043 \\
(0.041)\end{array}$ \\
\hline Observations & 333 & 333 & 333 & 333 & 333 & 333 \\
\hline \multirow[t]{2}{*}{ Panel B. } & \multicolumn{6}{|c|}{ Arrest Outcomes: Hispanic Students } \\
\hline & $\underline{\text { Ever Arrested }}$ & $\underline{\text { Arrests }}$ & $\underline{\text { Violent }}$ & $\underline{\text { Property }}$ & $\underline{\text { Drugs }}$ & $\underline{\text { Other }}$ \\
\hline Offer & $\begin{array}{c}0.046^{* *} \\
(0.023)\end{array}$ & $\begin{array}{c}0.036 \\
(0.128)\end{array}$ & $\begin{array}{l}-0.006 \\
(0.012)\end{array}$ & $\begin{array}{c}0.008 \\
(0.012)\end{array}$ & $\begin{array}{c}0.026^{* * *} \\
(0.010)\end{array}$ & $\begin{array}{c}0.015 \\
(0.017)\end{array}$ \\
\hline Observations & 706 & 706 & 706 & 706 & 706 & 706 \\
\hline \multirow[t]{2}{*}{ Panel C. } & \multicolumn{6}{|c|}{ Arrest Outcomes: Female Students } \\
\hline & $\underline{\text { Ever Arrested }}$ & $\underline{\text { Arrests }}$ & $\underline{\text { Violent }}$ & Property & $\underline{\text { Drugs }}$ & $\underline{\text { Other }}$ \\
\hline Offer & $\begin{array}{c}0.023 \\
(0.029)\end{array}$ & $\begin{array}{l}-0.087 \\
(0.158)\end{array}$ & $\begin{array}{c}0.018 \\
(0.011)\end{array}$ & $\begin{array}{l}-0.026 \\
(0.023)\end{array}$ & $\begin{array}{l}0.010^{*} \\
(0.006)\end{array}$ & $\begin{array}{c}0.025 \\
(0.023)\end{array}$ \\
\hline Observations & 582 & 582 & 582 & 582 & 582 & 582 \\
\hline Panel D. & \multicolumn{6}{|c|}{ Arrest Outcomes: Male Students } \\
\hline & Ever Arrested & $\underline{\text { Arrests }}$ & $\underline{\text { Violent }}$ & Property & $\underline{\text { Drugs }}$ & $\underline{\text { Other }}$ \\
\hline Offer & $\begin{array}{c}0.077^{* * *} \\
(0.025)\end{array}$ & $\begin{array}{c}0.080 \\
(0.138)\end{array}$ & $\begin{array}{l}-0.005 \\
(0.014)\end{array}$ & $\begin{array}{c}0.024^{* *} \\
(0.011)\end{array}$ & $\begin{array}{c}0.017 \\
(0.011)\end{array}$ & $\begin{array}{l}0.033^{*} \\
(0.020)\end{array}$ \\
\hline Observations & 622 & 622 & 622 & 622 & 622 & 622 \\
\hline
\end{tabular}

Regressions control for district admission probabilities, race, gender and age. See text for exact specification. Violent, Property, Drugs and Other are indicators for ever being arrested for an offense in each respective category. The sample is students age 18 and older at the time the application data were merged to arrest records. Robust standard errors shown in parentheses.

$* * * \mathrm{p}<0.01, * * \mathrm{p}<0.05, * \mathrm{p}<0.1$ 
Table 11: Voting Outcomes

\begin{tabular}{|c|c|c|c|c|}
\hline \multirow[t]{2}{*}{ Panel A. } & \multicolumn{2}{|c|}{ All Students } & \multicolumn{2}{|c|}{ Black Students } \\
\hline & Registered & Voted & $\underline{\text { Registered }}$ & Voted \\
\hline Offer & $\begin{array}{c}0.038 \\
(0.048)\end{array}$ & $\begin{array}{c}0.009 \\
(0.044)\end{array}$ & $\begin{array}{c}-0.020 \\
(0.111)\end{array}$ & $\begin{array}{c}-0.033 \\
(0.099)\end{array}$ \\
\hline Observations & 675 & 675 & 207 & 207 \\
\hline \multirow[t]{2}{*}{ Panel B. } & \multicolumn{2}{|c|}{ Hispanic Students } & \multicolumn{2}{|c|}{ Female Students } \\
\hline & $\underline{\text { Registered }}$ & Voted & $\underline{\text { Registered }}$ & Voted \\
\hline Offer & $\begin{array}{c}0.004 \\
(0.062)\end{array}$ & $\begin{array}{l}-0.007 \\
(0.057)\end{array}$ & $\begin{array}{l}-0.061 \\
(0.087)\end{array}$ & $\begin{array}{c}-0.113 \\
(0.084)\end{array}$ \\
\hline Observations & 378 & 378 & 323 & 323 \\
\hline \multirow[t]{2}{*}{ Panel B. } & \multicolumn{2}{|c|}{ Male Students } & & \\
\hline & $\underline{\text { Registered }}$ & Voted & & \\
\hline Offer & $\begin{array}{c}0.102^{*} \\
(0.056)\end{array}$ & $\begin{array}{c}0.082^{*} \\
(0.047)\end{array}$ & & \\
\hline Observations & 352 & 352 & & \\
\hline $\begin{array}{l}\text { Regressions contr } \\
\text { See text for exact } \\
\text { the time of the } 20 \\
\text { parentheses. }\end{array}$ & $\begin{array}{l}\text { for district adn } \\
\text { pecification. T } \\
2 \text { presidential }\end{array}$ & $\begin{array}{l}\text { sion proba } \\
\text { sample is } \\
\text { tion. Rob }\end{array}$ & $\begin{array}{l}\text { ilities, race, gen } \\
\text { tudents age } 18 \\
\text { st standard err }\end{array}$ & $\begin{array}{l}\text { r and age. } \\
\text { id older at } \\
\text { s shown in }\end{array}$ \\
\hline
\end{tabular}


